ACTA MYCOLOGICA

Vol. 48 (2): 237-245

2013
Dedicated to Professor Maria Ławrynowicz on the occasion of the 45th anniversary of her scientific activity

DOI: $10.5586 / \mathrm{am} .2013 .025$

\title{
Biomass, abundance and sensitivity to antibiotics and antimycotics of the fungi in the Vistula River with its main tributaries
}

\author{
ANNA PIETRYCZUK, ANDRZEJ STEFAN GÓRNIAK, \\ ADAM WIECKO and ADAM CUDOWSKI
}

Institute of Biology, University of Białystok, Świerkowa 20B

PL-15-950 Białystok, annapiet@uwb.edu.pl

Pietryczuk A., Górniak A.S., Więcko A., Cudowski A.: Biomass, abundance and sensitivity to antibiotics and antimycotics of the fungi in the Vistula River with its main tributaries. Acta Mycol.48 (2): 237-245, 2013.

Mycoplankton of Vistula River and its main tributaries biomass as well as the number and morphotype diversity was studied in summer and autumn 2011. Summer mycoplankton biomass was within the range of $0.2-0.5 \mu \mathrm{g} / \mathrm{l}$, while in the autumn it was two times wider range $(0.1-1.3$ $\mu \mathrm{g} / \mathrm{l})$. The number of fungi in river water most often did not exceed $1000-2000 \mathrm{CFU} / \mathrm{ml}$. Fungi colonies isolated from rivers water were sensitive to the commonly used amphotericine B (10 $\mu \mathrm{g})$ and gentamicin $(10 \mu \mathrm{g})$. It seems to be plausible that aquatic fungi can acquire immunity to drugs as a result of horizontal transfer of a gene responsible for drug resistance or as an effect of antibiotics and antimycotics getting into the aquatic ecosystems from wastewaters.

Key words: river, aquatic fungi, antibiotics, antimycotics

\section{INTRODUCTION}

Aquatic fungi are an important part of aquatic ecosystems and play a fundamental role in the functioning of water basins as well as take an active part in microbiological decomposition of organic matter (Seena et al. 2008), especially that of plant origin, preparing this substrate for colonization by other organisms, mainly invertebrates (Canhoto, Graca 2008). They also take an active part in alleviating the results of anthropogenic stressors since they participate in biotransformation of organic xenobiotics entering aquatic environments (Qi, Moe 2002; Miersch, Grancharov 2008). These characteristics point to participation of this group of organisms in the process of self-purification of waters which has been up until now ignored and their potential utilization in biotechnology (Wong et al. 1998; Pascoal et al. 2005; Krauss et al. 2011).

These days infections caused not only by pathogenic but also by saprotrophic fungi are becoming a growing problem. A factor which facilitates the invasion of host tissue 
is, among others, the acquired resistance to commonly used antifungal drugs. Studies reported that aquatic fungi are present in drinking water and accepted as impurities. Limit of the presence of fungi in the consumption water has been established by Swedish regulation authority at $100 \mathrm{CFU}$ per $100 \mathrm{ml}$ of water (Anon. 2003). However, the significance of fungi in drinking water for water quality and for human health still is unclear and disputed, because fungi existing in low abundance can affect diseases and allergies in humans (Flannigan et al. 1991; Doggett 2000; Anaissie et al. 2002; Hageskal et al. 2006; Hageskal et al. 2007; Hageskal et al. 2009). Additionally, aquatic microorganisms resistant to antibiotics can transmit this trait to pathogenic microorganisms, for example, through horizontal gene transfer, which can have a significant meaning to the health of humans and animals (Hill et al. 1994). Additionally, metabolically active antifungal drugs can enter aquatic environment along with agricultural waste and wastewaters, which also may result in acquiring resistance to these drugs by aquatic microorganisms. Therefore, aquatic fungi can be used as an ecological change indicator in aquatic ecosystems (Moore et al. 2010).

The aim of study was to determine the biomass level, abundance and morphotypes diversity of fungi in the course of Vistula River and its most important tributaries, as well as analysis of their resistance to common antibiotics and mycobiotics.

\section{MATERIALS AND METHODS}

The study included 23 stations on the course of Vistula River, the main river in Poland and its main tributaries starting at Goczałkowice reservoir to the Baltic See (Fig. 1). The study material was collected in August and October of 2011 and stored one day in a cool place in polyethylene bottles (1 l l) before analysis. Sample collections took place during two days each, at average level of river water. The study material was collected from surface water (up to $1 \mathrm{~m}$ ).

Unfiltered samples of water $(250 \mu \mathrm{l})$, diluted $(1: 10$ and 1:100) were cultured directly onto Petri plates containing chrolamphenicol (POCh) enriched Sabouraud agar. The plates were incubated at a temperature of $25^{\circ} \mathrm{C}$ for 5 days. After the incubation period the total number of colonies and different morphotypes of fungi within the colonies were determined (Descals 2007). The biomass of fungi suspended in water was calculated based on chromatographic quantitative analyses of ergosterol extracted from sestone remaining on the filter of glass fiber GF/G with a pore size of 0.7 microns after filtration of 11 of river water using the HPLC method according to Davis, Lamar (1992), Mille-Lindblom, Tranvik (2003) and Jurrgensen, Stepanauskas (2009). The chromatographic set consisted of the following modules: System Gold 125 Solvent Module, 166 Detector, Autosampler 502 made by the Beckman Company and a Computer equipped with the System Gold The Personal ${ }^{\mathrm{TM}}$ Chromatograph program. Chromatographic division was done at a temperature of 30 şC on a Beckman C18 Ultrasphere ODS $5 \mu 4.6 \mathrm{~mm} \times 250 \mathrm{~mm}$ column with the isocratic flow of methanol and distilled water solution at 98:2 volume proportions, set at the $1.5 \mathrm{ml} / \mathrm{min}$ level. Ergosterol was determined using a UV detector with wavelength $282 \mathrm{~nm}$ after elution time lasting approximately 11 minutes. Taking into account the fact that very small amounts of ergosterol were present in the river samples being analyzed, the standard addition method was used. To convert ergosterol to aquatic fungi biomass 


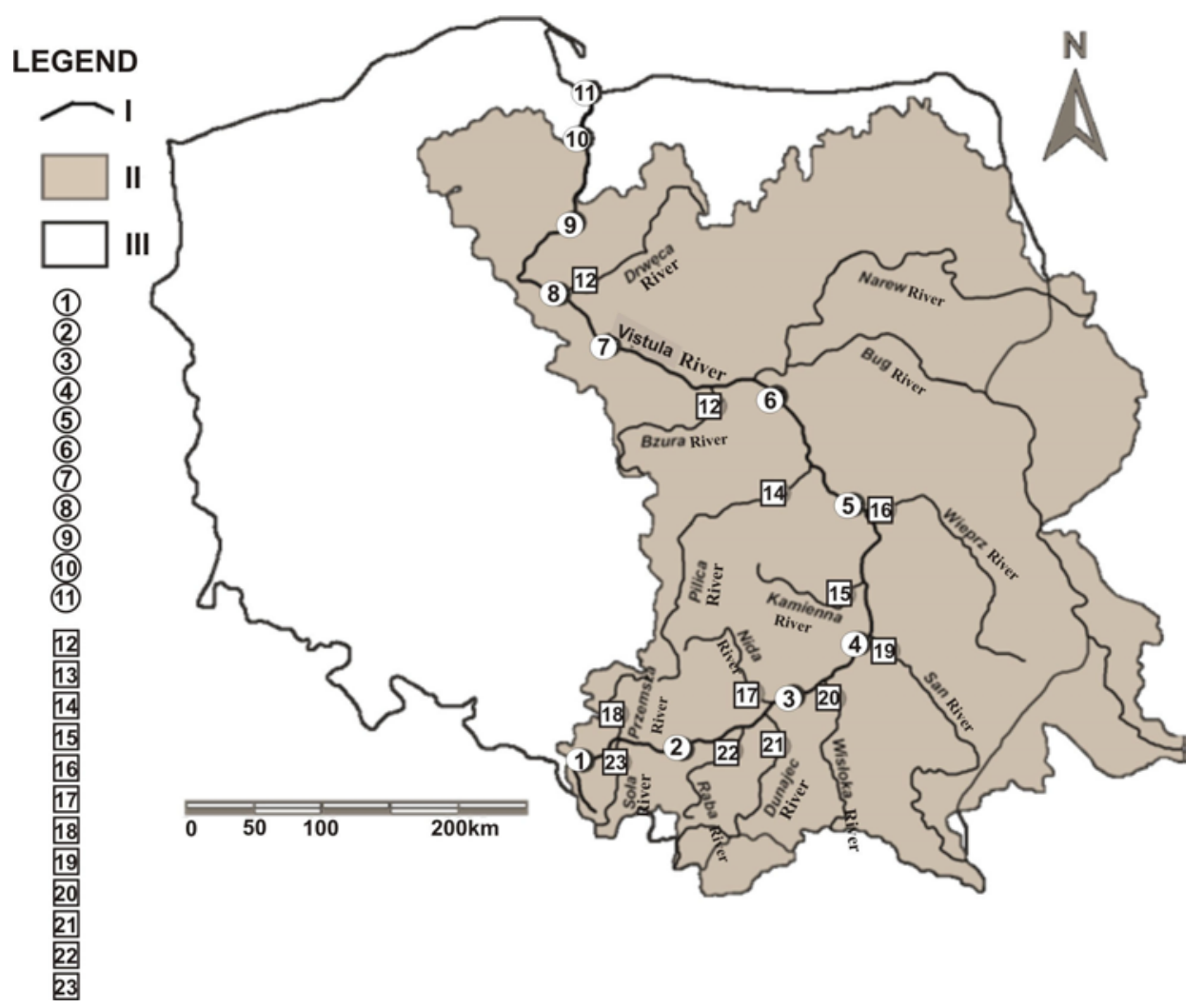

Fig. 1. Map of samples localization I - rivers, II - Vistula River catchment, III - polish border, circle - Station on Vistula River, quadrat - tributaries, station number as in Table 3.

a coefficient of $5.5 \mathrm{mg}$ of ergosterol in $1 \mathrm{~g}$ of aquatic fungi and $35 \%$ carbon content was used (Jřrgensen, Stepanauskas 2009). Method validation revealed that the reclamation of ergosterol released from carancules and propagules of the fungi is $91 \pm 3 \%$, and the method error does not exceed $0.1 \mu \mathrm{g} / \mathrm{l}$.

The assessment of sensitivity to commonly used antibiotics and anitmycotics was conducted using the disk diffusion method (Holt 1975). Substrate YNB was used for testing with the content: yeast extract $0.5 \%$, glucose $3 \%$, agar $1.8 \%$. The medium was sterilized for 20 minutes at 1.5 atmospheres and its $\mathrm{pH}$ was established at 7 . The medium was then deposited in a thin layer onto $90 \mathrm{~mm}$ diameter Petri plates. To assess sensitivity sterile discs impregnated with antibiotics: gentamiacin $(10 \mu \mathrm{g})$ and erythromycin $(15 \mu \mathrm{g})$ (Oxoid) as well as antimycotics: amphotericin B (10 $\mu \mathrm{g})$ and clotrimazol (10 $\mu \mathrm{g})$ (Liofilchem). Fungi suspension for assessment of sensitivity was obtained from 5 day old cultures raised on Sabouraud medium, by flushing morphotypes using $9 \mathrm{ml} 0.1 \%$ peptone saline (Oxoid CM0733). The resulting suspension was evenly spread on the surface of the YNB substrate, the excess was poured off and the top of the plate was left slightly agar at room temperature allowing drying of the substrate surface. Subsequently, onto the surface of the substrate paper disks saturated with the drugs were placed and the plates were incubated at a temperature of $25^{\circ} \mathrm{C}$. Sensitivity assessment was performed after 24 
Table 1

Interpretation of the results obtained using the disk-diffusion method of antibiotic and antimycotic sensitivity on the basis of the diameter of growth inhibition after 24 hours

\begin{tabular}{|c|c|c|c|}
\hline Drug & Sensitive & Intermediate & Resistant \\
\hline & Diameter of growth inhibition (in mm) & $<14$ \\
\hline Amphotericine B & $\geq 15$ & $10-14$ & $<14$ \\
\hline Clotrimazole & $\geq 18$ & $14-18$ & $\leq 13$ \\
\hline Erythromycin & $\geq 23$ & $14-22$ & $\leq 12$ \\
\hline Gentamiacin & $\geq 15$ & $13-14$ & \\
\hline
\end{tabular}

hours based on inhibition of growth according to a scale presented in Table 1 (Holt 1975; Moore et al. 2010).

The Student's t-test and Wilcoxon's test was used to estimate the difference between means. Differences of $p<0.05$ were considered as statistically significant.

\section{RESULTS AND DISCUSSION}

As a result of the conducted analyses it has been demonstrated that the number of morphotypes in the fungi colonies in the waters of the rivers being studies fluctuated between 1 and 4, and that greater diversification was noticed in the autumn compared to the summer. In the autumn a much greater biomass of fungi has been recorded (Fig. 2). The summer mycoplankton biomass usually fit within a range of $0.2-0.5 \mu \mathrm{g} / \mathrm{l}$, while in the autumn within a range of $0.1-1.3 \mu \mathrm{g} / \mathrm{l}$ (Tab. 2). The research conducted shows that the biomass of fungi assessed using the HPLC method is closely correlated with their abundance $\left(\mathrm{r}^{2}=0.975\right)($ Fig. 3$)$. The number of the fungi in rivers water usually did not exceed 1000-2000 CFU/ml and reached the maximum value of 24000-27000 CFU/ml. Additionally it has been shown that both the biomass and the number of the fungi reach the highest values in lowland rivers. The average biomass of fungi calculated for the lowland tributaries of Vistula is $0.63 \mu \mathrm{g} / \mathrm{l}$ and CFU is $3525 / \mathrm{ml}$, while in mountain rivers these values are $0.44 \mu \mathrm{g} / \mathrm{l}$ and $2800 \mathrm{CFU} / \mathrm{ml}$ respectively. The lowest fungi biomass was recorded in upland rivers in which the average value of biomass is $0.38 \mu \mathrm{g} / \mathrm{l}$ and their number is 2020 $\mathrm{CFU} / \mathrm{ml}$. The research regarding the abundance of aquatic fungi is so far conducted sporadically. To comparison in the three rivers in Argentina and the River Tinto (South-West Spain) there have been shown a maximum number of 8 kinds of aquatic fungi appearing with different frequency, mainly dependant on the time of year and day during which the samples were collected (López-Archilla et al. 2004; Marano, Steciow 2006; Sridhar, Sudheep 2010). Earlier reports shown however that in the first stages of the decomposition of plant matter, especially of the leaves which have fallen in the water, the fungi biomass fluctuates even in the range of $90-95 \%$ of the entire microorganism biomass in the water, which also could explain a greater number of fungi in the autumn compared to summer. It is additionally known that the variation of biomass and number of aquatic fungi also depends on other physico-chemical parameters of the water, such as $\mathrm{pH}$, temperature, access to nutrients, mainly nitrogen and phosphorus, as well as organic matter (Krauss et al. 2011). 
Table 2

Biomass, abundance and diversity of fungi morphotypes in the Vistula River and its main tributaries

\begin{tabular}{|c|c|c|c|c|c|c|c|c|}
\hline \multirow[t]{2}{*}{$\begin{array}{l}\text { Sample } \\
\text { number }\end{array}$} & \multirow[t]{2}{*}{ River } & \multirow[t]{2}{*}{ Station } & \multicolumn{2}{|c|}{$\begin{array}{l}\text { Biomass of fungi } \\
{[u \mathrm{~g} / 1]}\end{array}$} & \multicolumn{2}{|c|}{$\mathrm{CFU} / \mathrm{ml}$} & \multicolumn{2}{|c|}{$\begin{array}{c}\text { Number of fungi } \\
\text { morphotypes }\end{array}$} \\
\hline & & & $\begin{array}{c}\text { August } \\
2011\end{array}$ & $\begin{array}{l}\text { October } \\
2011\end{array}$ & $\begin{array}{c}\text { August } \\
2011\end{array}$ & $\begin{array}{l}\text { October } \\
2011\end{array}$ & $\begin{array}{c}\text { August } \\
2011\end{array}$ & $\begin{array}{c}\text { October } \\
2011\end{array}$ \\
\hline \multicolumn{9}{|c|}{ Vistula River } \\
\hline 1. & Vistula & Zabrzeg & 4.47 & 0.45 & 24000 & 1800 & 3.0 & 4.0 \\
\hline 2. & Vistula & Tyniec & 0.26 & 0.46 & 1900 & 2000 & 2.0 & 4.0 \\
\hline 3. & Vistula & Szczucin & 0.64 & 0.25 & 4000 & 1000 & 3.0 & 2.0 \\
\hline 4. & Vistula & Sandomierz & 0.31 & 0.96 & 2100 & 4500 & 4.0 & 4.0 \\
\hline 5. & Vistula & Dęblin & 6.14 & 0.47 & 27000 & 2700 & 1.0 & 4.0 \\
\hline 6. & Vistula & Warszawa & 0.30 & 0.20 & 2000 & 800 & 2.0 & 3.0 \\
\hline 7. & Vistula & Włocławek & 0.28 & 0.57 & 1900 & 2200 & 2.0 & 4.0 \\
\hline 8. & Vistula & Toruń & 0.36 & 1.25 & 2900 & 9200 & 1.0 & 4.0 \\
\hline 9. & Vistula & Grudziądz & 4.85 & 1.13 & 25200 & 7600 & 3.0 & 2.0 \\
\hline 10. & Vistula & Tczew & 0.26 & 1.02 & 1800 & 4600 & 2.0 & 3.0 \\
\hline 11. & Vistula & Świbno & 0.26 & 1.15 & 1800 & 7900 & 2.0 & 2.0 \\
\hline \multicolumn{9}{|c|}{ lowland rivers } \\
\hline 12. & Drwęca & Lubicz & 0.26 & 1.13 & 1800 & 7800 & 2.0 & 3.0 \\
\hline 13. & Bzura & Żuków & 0.47 & 0.66 & 2200 & 2300 & 2.0 & 4.0 \\
\hline 14. & Pilica & Białobrzegi & 0.44 & 0.49 & 2900 & 2400 & 3.0 & 2.0 \\
\hline \multicolumn{9}{|c|}{ upland rivers } \\
\hline 15. & Kamienna & Czekarzewice & 0.36 & 0.40 & 2300 & 1600 & 2.0 & 2.0 \\
\hline 16. & Wieprz & Dęblin & 0.30 & 0.75 & 1900 & 2100 & 2.0 & 3.0 \\
\hline 17. & Nida & Połaniec & 0.02 & 0.16 & 500 & 400 & 3.0 & 4.0 \\
\hline 18. & Przemsza & Chełmek & 0.24 & 0.94 & 1600 & 4000 & 4.0 & 4.0 \\
\hline \multicolumn{9}{|c|}{ mountain rivers } \\
\hline 19. & San & Radomyśl & 0.43 & 0.26 & 2900 & 1100 & 4.0 & 3.0 \\
\hline 20. & Wisłoka & Gawłuszowice & 0.44 & 0.25 & 3000 & 1100 & 1.0 & 2.0 \\
\hline 21. & Dunajec & Źabno & 0.34 & 0.79 & 2200 & 3900 & 1.0 & 1.0 \\
\hline 22. & Raba & Chełm & 0.92 & 0.20 & 8200 & 900 & 1.0 & 3.0 \\
\hline 23. & Soła & Oświęcim & 0.66 & 0.10 & 4500 & 200 & 4.0 & 4.0 \\
\hline
\end{tabular}

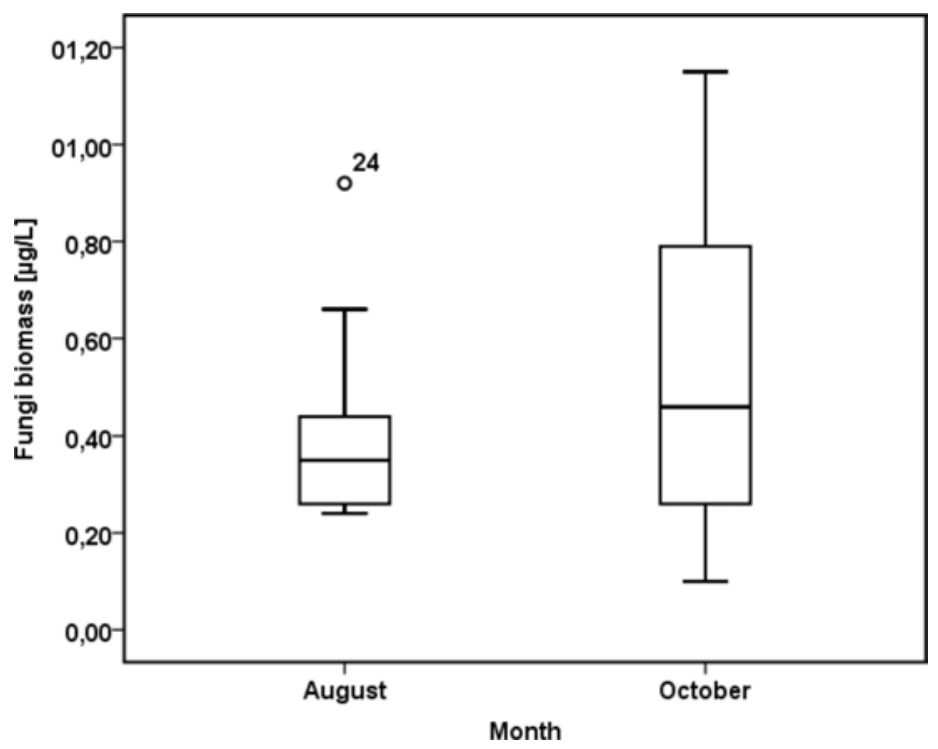

Fig. 2. Changes in the abundance of fungi in each month (average values). 
Table 3

Assessment of sensitivity to antibiotics and antimykotics of various fungi morphotypes isolated from the surface waters of the Vistula River and its tributaries $(\mathrm{p}<0.05)$

\begin{tabular}{|c|c|c|c|c|c|c|}
\hline Sample & River & Station & \multicolumn{4}{|c|}{ Drug sensitivity } \\
\hline \multicolumn{7}{|c|}{ Vistula River } \\
\hline & & & AMB & GM & $E$ & $\mathrm{~S}$ \\
\hline 1. & Vistula & Zabrzeg & I & $\mathrm{R}$ & $\mathrm{R}$ & $\mathrm{R}$ \\
\hline 2. & Vistula & Tyniec & I & $\mathrm{R}$ & $\mathrm{R}$ & $\mathrm{R}$ \\
\hline 3. & Vistula & Szczucin & $\mathrm{I}$ & $\mathrm{I}$ & $\mathrm{R}$ & $\mathrm{R}$ \\
\hline 4. & Vistula & Sandomierz & I & I & $\mathrm{R}$ & $\mathrm{R}$ \\
\hline 5. & Vistula & Deblin & I & I & $\mathrm{R}$ & $\mathrm{R}$ \\
\hline 6. & Vistula & Warszawa & I & $\mathrm{R}$ & $\mathrm{R}$ & $\mathrm{R}$ \\
\hline 7. & Vistula & Włoclawek & I & $\mathrm{R}$ & $\mathrm{R}$ & $\mathrm{R}$ \\
\hline 8. & Vistula & Toruń & $\mathrm{R}$ & $\mathrm{I}$ & $\mathrm{R}$ & $\mathrm{R}$ \\
\hline 9. & Vistula & Grudziadz & $\mathrm{R}$ & I & $\mathrm{R}$ & $\mathrm{R}$ \\
\hline 10. & Vistula & Tczew & $\mathrm{R}$ & $\mathrm{I}$ & $\mathrm{R}$ & $\mathrm{R}$ \\
\hline 11. & Vistula & Swibno & $\mathrm{R}$ & I & $\mathrm{R}$ & $\mathrm{R}$ \\
\hline \multicolumn{7}{|c|}{ mountain rivers } \\
\hline 12. & Sola & Oświecim & I & $\mathrm{R}$ & $\mathrm{R}$ & $\mathrm{R}$ \\
\hline 13. & San & Wrzawy & $\mathrm{I}$ & $\mathrm{I}$ & $\mathrm{R}$ & $\mathrm{R}$ \\
\hline 14. & Raba & Chelm & I & I & $\mathrm{R}$ & $\mathrm{R}$ \\
\hline 15. & Dunajec & Źabno & I & $\mathrm{R}$ & $\mathrm{R}$ & $\mathrm{R}$ \\
\hline 16. & Wisloka & Gawhuszowice & I & I & $\mathrm{R}$ & $\mathrm{R}$ \\
\hline \multicolumn{7}{|c|}{ upland rivers } \\
\hline 17. & Nida & Polaniec & I & I & $\mathrm{R}$ & $\mathrm{R}$ \\
\hline 18. & Kamienna & Czekarzewice & $\mathrm{I}$ & $\mathrm{R}$ & $\mathrm{R}$ & $\mathrm{R}$ \\
\hline 19. & Wieprz & Deblin & $\mathrm{R}$ & $\mathrm{R}$ & $\mathrm{R}$ & $\mathrm{R}$ \\
\hline 20. & Przemsza & Chelmek & I & $\mathrm{S}$ & $\mathrm{R}$ & $\mathrm{R}$ \\
\hline \multicolumn{7}{|c|}{ lowland rivers } \\
\hline 21. & Pilica & Bialobrzegi & I & $\mathrm{R}$ & $\mathrm{R}$ & $\mathrm{R}$ \\
\hline 22. & Bzura & Zuków & $\mathrm{R}$ & $\mathrm{I}$ & $\mathrm{R}$ & $\mathrm{R}$ \\
\hline 23. & Drweca & Lubicz & I & I & $\mathrm{R}$ & $\mathrm{R}$ \\
\hline
\end{tabular}

Abbreviations. GM - gentamycyna (10 $\mu \mathrm{g}), \mathrm{AMB}$ - amfoterycyna B (10 $\mu \mathrm{g}), \mathrm{E}$ - erytromycyna (15 $\mu \mathrm{g})$, $\mathrm{S}$ - klotrimazol (10 $\mathrm{gg}), \mathrm{S}$ - sensitivity, I -intermediate, $\mathrm{R}$ - resistant

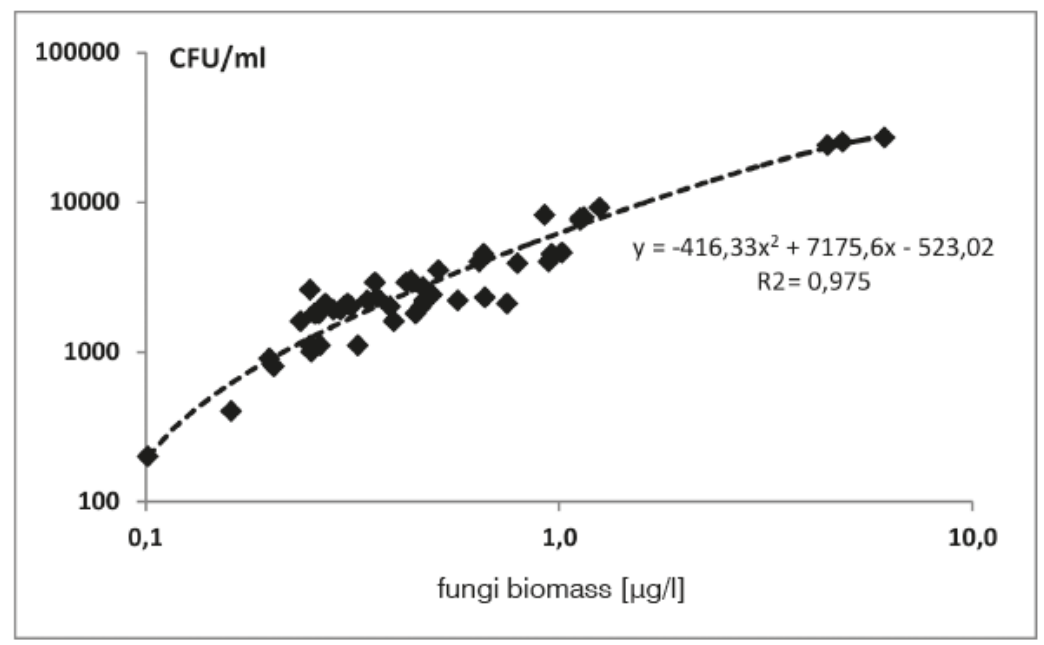

Fig. 3. Correlation between the number $(\mathrm{CFU} / \mathrm{mL})$, and fungi biomass $(\mu \mathrm{g} / \mathrm{L})$ in the Vistula River and its main tributaries. 
Since in the last few years the infections caused by fungi, and not only the pathogenic ones but also the saprothropic, are becoming a growing problem, research has been conducted on the drug-resistance of fungi from the Vistula River and its tributaries. River water fungi resistance for commonly used antimycotics and antibiotics were analyzed too. It turned out that only in the 6 from 23 rivers being studied there were morphotypes immune to amphotericin B (Tab. 3). This is a substance belonging to very potent polyene antifungal antibiotics, which bind with the steroids of the cell membranes causing an increased level of their permeability which in turn leads to disruption of metabolic processes and necrosis of the cell of the fungus. Since only a small number of examined fungi ansambles is not sensitive to this mycotic it seems that they must have acquired immunity to amphotericine B. Additionally in as many as in $50 \%$ of the positions examined samples of water fungi sensitive to gentamicin, which is a typical antibiotic, have been identified. Fungi sensitive to erythromycin have not been identified in any of the rivers, and what is more interesting to clotrimazone, which is an imadazole inhibiting ergosterol synthesis and having a very wide effective spectrum (Rufo et al. 1997; Gruszecki et al. 2009).

Numerous literary data concerning, however, mainly bacteria occurring in surface waters reports that the saprotrophic microorganism populations are acquiring immunity to antibiotics from other microorganisms, also pathogenic, mainly through horizontal gene transfer, as well as through contact with antibiotics and other drugs added to cosmetics and detergents entering aquatic ecosystems with sewage (Gotz, Smalla 1997; Kim, Aga 2007; Zebouh et al. 2008; Kümmerer 2009). Our own research and the above mentioned literary data indicate that a similar mechanism of acquiring immunity to drugs can also concern aquatic fungi. Similarly as in our research the analyses conducted by Moore et al. (2010) indicated the occurrence in only two types of aquatic environments phenotypes of saprothropic bacteria resistant to aminoglycosides, which are a very powerful antibacterial compounds with wide range of effectiveness. Similarly amphotericin B is a powerful antifungal drug, but fungi originating from 5 rivers were characterized by immunity to this drug. Since as many as 3 stations on the Vistula River were characterized by the occurrence of colonies resistant to amphotericin B it could be concluded that large quantities of antibiotics, which can change the interaction between organisms and with this contribute to the disruption of ecological relationships, entering the river. Published studies report that microorganisms coming from natural aquatic environments can transmit drug resistance to pathogenic microorganisms (Moore et al. 2010). This mechanism is probably also present within mycoplankton. Saprotrophic fungi are present in drinking water and their standard number is $100 \mathrm{CFU} / \mathrm{mL}$. The presence of fungi has been ascertained not only in bottled water but also in distilled and in ultraclean water (Cabral, Fernandez 2002; Hageskal et al. 2006; Ribeiro et al. 2006; Hageskal et al. 2009). The fungi present in drinking water can transfer drug-resistance to pathogenic microorganisms, and that has significant meaning when it comes to the health of humans. The fact that up until now the occurrence of numerous species of pathogenic fungi resistant to amphotericin $\mathrm{B}$ has been detected can serve as confirmation of this (Bossche et al. 1994).

Antibiotics and mycobiotics as a secondary metabolites produced by microorganisms also take part in shaping the ecological relationships in aquatic ecosystems. They can neutralize heavy metals or take the form of toxins and regulate the activity of other organisms as well as the interaction between organisms. To recognize changes in number, biomass and morphotype variety of aquatic fungi as well as their drug resistance, can present a picture of ecological changes occurring in aquatic ecosystems, and also have 
significant meaning in the protection of and monitoring of the water environment. Additionally detailed recognition of the mechanisms of acquiring drug resistance by aquatic microorganisms can contribute to better understanding of how antibiotic and antimycotic mechanisms act upon pathogenic microorganisms (Ho et al. 2003).

Aknowlegements. Research was founded by Polish National Science Center in project NN304375938. Anonymous reviewers are thanked for their critical comments and suggestions.

\section{REFERENCES}

Anaissie E.J., Penzak S.R., Dignani M.C. 2002. The hospital water supply as a source of nosocomial infections. A plea for action. Archv. Internal Med. 162: 1483-1492.

Anon. 2003. Drinking water regulations (in Swedish). SLVFS 2001: 30. National Food Administration, Stockholm, Sweden.

Bossche H.V., Marichal P., Odds F.C. 1994. Molecular mechanisms of drug resistance in fungi. Trends Microbiol. 2: 393-400.

Cabral D., Fernández P. 2002. Fungal spoilage of bottled mineral water. Intern. J. Food Microbiol. 72: 73-76.

Canhoto C., Graca M.A.S. 2008. Interactions between fungi and stream invertebrates: back to the future, Novel techniques and ideas in mycology, Fungal diversity research series (Sridhar K.R., Bärlocher F., Hyde K.D., eds), pp. Fungal Diversity Press, Yunnan, P.R. China: 305-325.

Davis M.W., Lamar, R. T. 1992. Evaluation of methods to extract ergosterol for quantitation of soil fungal biomass. Soil Biol Biochem. 24 (3): 189-198.

Descals E. 2007. Techniques for handling ingoldian fungi. (In:) M.A.S. Graça, F. Bärlocher, M.O. Gessner (eds). Methods to study litter decomposition. A practical guide. Springer: 129-141.

Doggett M.S. 2000. Characterization of fungal biofilms within a municipal water distribution system. Appl. Environ. Microbiol. 66: 1249-1251. http://dx.doi.org/10.1128\%2FAEM.66.3.1249-1251.2000

Flannigan B., McCabe E.M., McGarry F. 1991. Allergenic and toxigenic microorganisms in houses. J. Appl. Bacteriol. Symp. Suppl. 70: 61S-73S.

Gotz A., Smalla K. 1997. Manure enhances plasmid mobilization and survival in Pseudomonas putida introduced into the field soil. Appl. Environ. Microbiol. 63: 1980-1986.

Gruszecki W.I., Luchowski R., Gagoś M., Arczewska M., Sarkar P., Hereć M., Myśliwa-Kurdziel B., Strzałka K., Gryczynski I., Gryczynski Z. 2009. Molecular organization of antifungal antibiotic amphotericin B in lipid monolayers studied by means of Fluorescence Lifetime Imaging Microscopy. Biophysics Chem. 143: 95-101.

Hageskal G., Knutsen A.K., Gaustad P., de Hoog G.S., Skaar I. 2006. Diversity and significance of mold species in Norwegian drinking water. Appl. Environ. Microbiol. 72: 7586-7593. http://dx.doi. org/10.1128\%2FAEM.01628-06

Hageskal G., Gaustad P., Heier B.T., Skaar I. 2007. Occurrence of moulds in drinking water. J. Appl. Microbiol. 102: 774-780. http://dx.doi.org/10.1111\%2Fj.1365-2672.2006.03119.x

Hageskal G., Lima N., Skaar I. 2009. The study of fungi in drinking water. Mycol. Res. 113: 165-172. http://dx.doi.org/10.1016\%2Fj.mycres.2008.10.002

Hill K.E., Fry J.C., Weightman A.J. 1994. Gene transfer in the aquatic environment: persistence and mobilization of the catabolic recombinant plasmid pD10 in the epilithon. Microbiol. 140: 1555-1563.

Ho W.H., To P.C., Hyde K.D. 2003. Induction of antibiotic production of freshwater fungi using mixculture fermentation. Fungal Diversity 12: 45-51.

Holt R.J. 1975. Laboratory tests of antifungal drugs. J. Clin. Path. 28: 767-774.

Jørgensen N.O.G., Stepanauskas R. 2009. Biomass of pelagic fungi in Baltic rivers. Hydrobiologia 623:105-112. http://dx.doi.org/10.1007\%2Fs10750-008-9651-2

Kim S., Aga D.S. 2007. Potential ecological and human health impact of antibiotics and antibiotic-resistant bacteria from wastewater treatment plants. J. Toxicol. Environ. Health 10: 559-573.

Krauss G.J., Solé M., Krauss G., Schlosser D., Wesenberg D., Bärlocher F. 2011. Fungi in freshwaters: ecology, physiology and biochemical potetntial. FEMS Microbial. Rev. 35: 620-651. 
Kümmerer K. 2009. The presence of pharmaceuticals in the environment due to human use: present knowledge and future challenges. J. Environ. Manage 90: 2354-2366.

López-Archilla A.I., González A.E., Terrón M.C., Amils R. 2004. Ecological study of the fungal populations of the acidic Tinto River in southwestern Spain. Can. J. Microbiol. 50: 923-934.

Marano A.V., Steciow M.M. 2006. Frequency and abundance of zoosporic fungi in some lotic environments of Buenos Aires Province (Argentina). J. Agr. Tech. 2(1): 17-28.

Miersch J., Grancharov K. 2008. Cadmium and heat response of the fungus Heliscus lugdunensis isolated from highly polluted and unpolluted areas. Amino Acids 34: 271-277.

Mille-Lindblom C., Tranvik L.J. 2003. Antagonism between bacteria and fungi on decomposing aquatic plant litter. Microb Ecol. 45: 173-182. http://dx.doi.org/10.1007\%2Fs00248-002-2030-z

Moore J.E., Rao J.R., Moore P.J.A., Millar B.C., Goldsmith C.E., Loughrey A., Rooney P.J. 2010. Determination of total antibiotic resistance in waterborne bacteria in rivers and streams in Northern Ireland: Can antibiotic-resistant bacteria be an indicator of ecological change? Aquat. Ecol. 44: 349-358.

Pascoal C., Cássio F., Marcotegui A., Sanz B., Gomes P. 2005. Role of fungi, bacteria and invertebrates in leaf litter breakdown in a polluted river. J N Am. Benthol. Soc. 24: 784-797.

Qi B., Moe W. 2002. Biodegradation of volatile organic compounds by five fungal species. Appl. Microbiol. Bot. 58: 684-689.

Ribeiro A., Machado A.P., Kozakiewicz Z., Ryan M., Luke B,. Buddie A.G., Venăncio A. Lima N., Kelley J. 2006. Fungi in bottled water: a case study of production plants. Revista Iberoamericana de Micologia 23: 139-144.

Rufo P.A., Merlin D., Riegler M., Ferguson-Maltzman M.H., Dickinson B.L., Brugnara C., Alper S.L., Lencer W.I. 1997. The antifungal antibiotic, clotrimazole, inhibits chloride secretion by human intestinal T84 cells via blockade of distinct basolateral K+ conductances. Demonstration of efficacy in intact rabbit colon and in an in vivo mouse model of cholera. J Clin. Invest. 100: 3111-3120.

Seena S., Wynberg N., Bärlocher F. 2008. Fungal diversity during leaf decomposition in a stream assessed through clone libraries. Fungal Divers. 30: 1-14.

Sridhar K.R., Sudheep N.M. 2010. Diurnal fluctuation of spores of freshwater hyphomycetes in two tropical streams. Mycosphere 1: 89-101.

Wong M.K.M., Goh T.K., Hodgkiss I.J., Hyde K.D., Ranghoo V.M., Tsui C.K.M., Ho W.H., Wong W.S.W., Yuen T.K. 1998. Role of fungi in freshwater ecosystems. Biodiversity and Conservation 7: 1187-1206.

Zebouh M., Thomas C., Honderlick P., Lemee L., Segonds C., Wallet F., Husson M.O. 2008. Direct antimicrobial susceptibility testing method for analysis of sputum collected from patients with cystic fibrosis. J. Cyst. Fibros. 7: 238-243. http://dx.doi.org/10.1016\%2Fj.jcf.2007.10.002

\section{Biomasa, liczebność i wrażliwość na antybiotyki i antymykotyki grzybów w Wiśle i jej głównych dopływach}

\section{Streszczenie}

Latem i jesienią 2011 roku określono biomasę oraz różnorodność morfotypów mykoplanktonu w wodach powierzchniowych Wisły i jej głównych dopływów. Letnia biomasa mykoplanktonu mieściła się w zakresie $0,2-0,5 \mu \mathrm{g} / \mathrm{L}$, zaś jesienią w przedziale $0,1-1,3 \mu \mathrm{g} / \mathrm{L}$. Liczebność grzybów w wodach rzecznych najczęściej nie przekraczała 1000-2000 CFU/mL. Próbki wody charakteryzowały się obecnością grzybów wrażliwych na powszechnie stosowany mikotyk amfoterycynę B $(10 \mu \mathrm{g})$ i antybiotyk gentamycynę $(10 \mu \mathrm{g})$. Wydaję się prawdopodobne, że grzyby wodne mogą nabywać oporność na leki, w wyniku horyzontalnego transferu genu odpowiedzialnego za lekooporność od innych mikroorganizmów lub wskutek dostawania się antybiotyków i antymikotyków ze ściekami do ekosystemów wodnych. 